\title{
Nicholas Carr
}

\section{Plitko: što Internet čini našem mozgu}

\author{
Naklada Jesenski i Turk, Zagreb 2011., 325 str.
}

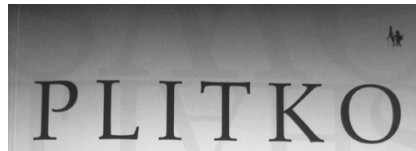

Što Internet čini našem mozgu

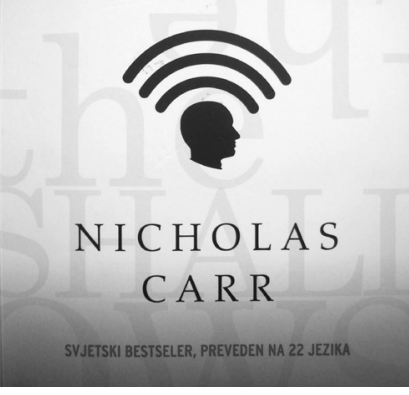

Nicholas Carr američki je pisac koji se bavi problematikom informacijsko-komunikacijskih tehnologija i njihovih utjecaja na kulturu i poslovanje. Objavio je niz novinskih članaka, eseja te nekoliko knjiga, među kojima je najpoznatija Plitko: što Internet čini našem mozgu. U knjizi se na interesantan i dinamičan način isprepliću popularna znanost i subjektivno iskustvo, a fokus je na konzumaciji novih komunikacijskih tehnologija te nizu promjena koje unose u čovjekov mentalni sklop. Knjigu čine prolog, deset poglavlja, četiri potpoglavlja (digresije), epilog te popis literature.

Osnovna nit prologa Pas čuvar i kradljivac, ali i cijele knjige, jest McLuhanova teza ,,medij je poruka”. Drugim riječima, sam medij, više nego njegov sadržaj, utječe na naše razmišljanje i djelovanje. U tom smislu, autor nagovještava bavljenje aspektom utjecaja tehnologije na neke kognitivne elemente.

Carr počinje od vlastitog dojma i osjećaja mentalne promjene u vlastitom umu. Kroz prvo poglavlje, pod simboličnim nazivom Hal i ja, paralelno iznosi razvoj računala i Interneta, svoje odrastanje te osobnu „anamnezu“ korištenja te tehnologije. Slabu usredotočenost na tekst i nemogućnost dubinskog čitanja, što mu prije nije predstavljao napor, pripisuje dugogodišnjem korištenju Interneta. Priznaje sve prednosti te tehnologije i koliko je utjecala na život modernog čovjeka učinivši ga „pametnijim u kraćem roku, dok se s druge strane se ne može oteti dojmu da se njezinim korištenjem u konačnici znatno mijenjaju mentalne navike kod čovjeka".

U poglavlju Životni putovi autor iznosi tvrdnju o neuroplastičnosti ljudskog mozga, osvrćući se na niz istraživanja koja su potvrdila da se neuronske veze i mentalni sklopovi mogu mijenjati i da nisu kruti, kao što se nekad smatralo. Promjene u mentalnom sklopu ovise o ponavljanju određenih radnji, što rezultira određenom vještinom, koja isto tako može nestati ukoliko se prestane s njenom izvedbom.

U narednom poglavlju, Mentalni instrumenti, neuroplastičnost mozga prikazana je u relaciji s tehnologijom. Autor tehnologiju određuje kao voljni čin kojim čovjek želi proširiti moć i kontrolu nad okolnostima u kojima živi, bilo da se radi o prirodi, 
čovjeku ili nekom drugom cilju. S obzirom da se tehnologije razlikuju prema cilju te su podijeljene u nekoliko skupina, u ovom su kontekstu izdvojene tzv. intelektualne tehnologije (str. 67). One takoreći obuhvaćaju sve instrumente kojima čovjek želi proširiti svoje mentalne sposobnosti. Kao primjere navodi kartografiju i sat. Kartografija se tehnički postepeno razvijala kroz povijest da bi u konačnici utjecala na to kako razmišljamo o prostoru, kako ga percipiramo te koristimo rječnik kartografije. Mjerenje, označavanje te poimanje vremena isto je tako jedan tip tehnologije koji je oblikovao život čovjeka i njegov doživljaj samog sebe. Navedeni su predmeti došli do faze koju Carr naziva minijaturizacija tebnologije, u smislu funkcionalnosti, dostupnosti, praktičnosti rukovanja te same personalizacije korištenja. Već je u ovom obrascu vidljiva sličnost sa strojevima modernih komunikacijskih tehnologija. Svaka intelektualna tehnologija posjeduje svojstvenu intelektualnu etiku kao skup pretpostavki o tome kako funkcionira ili kako bi trebao funkcionirati ljudski um. U tom smislu, Carr priznaje argumente tehnološkog instrumentalizma, iako se više bavi determinističkim segmentom tehnologije - kako ona utječe na čovjeka i društvo. Pismenost, odnosno savladavanje vještine čitanja i pisanja jedan je primjer oblikovanja čvrstih mentalnih sklopova koji su uvijek aktivni kod radnji kao što su čitanje ili pisanje.

U poglavlju Udubljena stranica u je kratkim crtama iznesen povijesni razvoj pisma i pismenosti. Autor opisuje razvoj umijeća pisanja pod utjecajem oralne kulture. Zapisivanje onoga što se točno čuje bez korištenja razmaka primjer je kognitivne neusklađenosti onoga što se čuje i onoga što se vidi i čita. Postepenim uvođenjem i korištenjem razmaka te standardizacijom interpunkcijskih znakova, kao i poretka riječi u rečenici, omogućeno je da ljudi čitaju brže i s više razumijevanja. Pisanje je postalo individualna aktivnost. Autori koji su prethodno diktirali pisarima, počeli su samostalno uređivati svoja djela. Carr to ističe kao važan moment u doživljaju čitanja i pisanja kod samog pojedinca. Individualnost i osobni doživljaj postaju bitne odrednice daljnjeg razvoja ljudskog uma. Izumom tiska pokrenuta je era tehnologije knjige, koja ima drukčiju intelektualnu etiku od tehnologije pisanja, a koja je bila usko vezana uz oralnu kulturu. Etika knjige zasnivala se na individualnom činu razvoja znanja, čija je glavna odrednica tzv. „čitanje u sebi“. U ovom dijelu Carr pojašnjava aktivnost dubinskog čitanja knjige iz perspektive neuroloških istraživanja te visoko vrednuje povezanost knjige i čitatelja. Odnos čitatelja i knjige u autorovom je opisu intiman i pomalo romantičarski prikazan. Kao kod karte i sata, minijaturizacija je knjige prethodila tome da postane glavnim medijem razmjene znanja, temeljem kulture te ključnom u oblikovanju ljudske svijesti. Autor se dosta bavi knjigom i tekstom jer je upravo tekst prvi postavljen u digitalnom formatu na Mrežu, tj. Internet, a slijedili su ga audio i videozapisi.

Razvoj Interneta ka multimedijalnosti prikazan je u poglavlju Medij najopćenitije prirode. Navedena je karakteristika dovela do znatnih promjena u korištenju medija (starih i novih, tiskanih i elektroničkih). Struktura Mreže i kolanja informacija ne prati strukturu ni logiku tiskanih medija. Ona je dvosmjerna i fragmentirana te svaki pojedinac ima mogućnost samostalno kreirati i objavljivati sadržaj te ga učiniti dostupnim drugima uključenima u Mrežu. Fragmentiranost, interaktivnost, pretraživost, stalna uključenost u sve kanale te prethodno spomenuta multimedijalnost za 
autora su ključna obilježja kod promatranja neurološke i kognitivne komponente. Dinamična kombinacija teksta, audio i videoisječaka na istoj web-stranici, uz navigacijske elemente i reklame, dekoncentrira i onemogućuje kontinuirano praćenje sadržaja; autor stoga koristi naziv „tehnologije prekidanja“. Osim što mijenja um, taj medij najopćenitije prirode utječe na formu i sadržaj tiskanih medija, ali i organizaciju prostora samih knjižnica. Kako autor tvrdi, „u središtu stoji ekran kompjutera povezanog na Internet; tiskana riječ izgurana je na margine“ (str. 135).

Carr dalje nastavlja sa sučeljavanjem knjige i Interneta. Poglavlje Slika i prilika knjige prikazuje kako knjiga, u odnosu na druge medije, donekle odolijeva trendu potpune digitalizacije. U digitalnom se okruženju sadržaj knjige mijenja jer je čitatelju omogućen neposredan pristup nizu informacija vezanih uz autora knjige, neke njezine dijelove ili zanimljivosti. Carr je stajališta da to obilje informacija mijenja njezin autentični sadržaj: ,Jednom kad smo postigli da se knjige mogu otkrivati i pretraživati na Internetu, time smo ih i razudili. Žrtvovali smo koheziju njihova teksta, linearnost argumenta ili pripovjedne niti koji teku njenim brojnim stranicama" (str. 220). Obilje informacija i poveznica ometa čitatelja u kvalitetnom čitanju. On više nije i ne može biti usredotočen na samo jednu stvar.

Poglavlje Žonglerov mozak donosi potvrdu teze kroz zaključke niza istraživanja o utjecaju Interneta na učenje, znanje, efikasnost u izvršavanju zadataka te sam mentalni sklop. Sve izneseno ide u prilog tome kako Internet obiljem informacija i raznoraznim alatima umanjuje koncentraciju korisnika, odnosno predstavlja „kognitivno opterećenje“. Iako rad u takvom okruženju nije posve loš jer uči pojedinca brzini pronalaženja informacija i rješavanja problema, stalnim preusmjeravanjem pažnje snosimo „troškove prebacivanja“. Troškovi su ustvari vrijeme koje je potrebno da se mozak usmjeri na ciljeve jednog, a zanemari ciljeve prethodno obavljanog, a nedovršenog zadatka. Razumljivo, u takvim uvjetima vjerojatnost pogrešnog tumačenja ili previda određene informacije je veća. Hipertekstualnost, kao jedna od ključnih karakteristika, umanjuje koncentraciju te samim time onemogućava „linearno“ i dubinsko čitanje teksta. Carr naglašava kako se stil čitanja mijenja te dijagonalno čitanje postaje uobičajenim stilom čitanja.

Google je osobit primjer alata koji nastoji utjeloviti efikasnost, sveobuhvatnost informacija i interaktivnost. U poglavlju Crkva Google autor ukratko analizira temelje intelektualne etike tvrtke Googleplex, koji počivaju na teorijskim postavkama tejlorizma. Ključne su odrednice efikasnost i numerička točnost. Ideja je tvoraca Googlea da poveznice među web-stranicama mogu funkcionirati kao citati u znanstvenom području: svaki odabir određene web-stranice (klik) takoreći predstavlja jedan citat. Što više klikova stranica ima, time je relevantnija, što je jedan od kriterija kod pretraživanja. Google je brzo postao najpopularnijim navigacijskim web-alatom, a tvorci ostvarili multimilijunsku zaradu. Carr posvećuje nekoliko stranica prikazu najambicioznije, no iz niza razloga problematične Googleplexove inicijative (poznate kao Google Print, odnosno Google Book Search). Radi se o digitalizaciji knjiga s ciljem formiranja globalne baze podataka, globalne knjižnice. Autor je vrlo nesklon ideji o mogućnosti digitalnog preoblikovanja knjiga od pojedinca. Unatoč tome što misli da takvi i slični alati nisu posve beskorisni, zamjera iskorištavanje knjiga i književnih djela kao pukih podataka jer se time dira u njihovu autentičnost. 
Uz pitanje komercijalizacije informacija, Carr se dotaknuo problematike umjetne inteligencije. Tvrdi da ljudski um ne funkcionira matematički poput računalnog te da je povezanost uma i određenih razina mozga relativno nepoznata i neistražena. U tom pogledu, stvaranje umjetnog mozga sa sposobnostima ljudskog praktički je neizvedivo. Unatoč tome, ono što smatra problematičnim jest ,uglavljena koncepcija ljudskog uma“ iz koje proizlazi želja za stvaranjem umjetne inteligencije.

Autor se dotiče pitanja pamćenja i sjećanja, koji postaju sve više prepušteni Mreži. U poglavlju Pretraživanje i pamćenje ukazuje na razliku između biološkog pamćenja i računalne memorije. Biološko je pamćenje složen i živ proces kojim je određeno kako se pohranjuju sjećanja, a kvaliteta sjećanja ovisna je o načinu obrade informacija. Mreža ima memoriju, prostor da obuhvati sve informacije koje možemo naći uvijek iznova, ali nam ne može pružiti kvalitetnu obradu tih informacija jer nema sposobnost biološkog pamćenja. Mreža previše okupira našu „radnu memoriju“, odnosno kratkoročno ili tzv. radno pamćenje te tako zaustavlja proces prelaska misli iz kratkoročnog pamćenja u dugoročno. Drugim riječima, prekida se proces apstrahiranja te formiranja znanja.

U posljednjem poglavlju, Stvar kao ja, Carr razmatra odnos između softvera, efikasnosti i vještine. Referirajući se na istraživanja, autor konstatira kako prepuštanjem strojevima da riješe određen problem ljudi gube specifične sposobnosti potrebne za rješavanje tog problema. Tehnološki je napredak odvojio čovjeka od aktivnosti koje mogu obavljati strojevi, te je time omogućen razvoj neke druge sposobnosti i vještine, vještine koje strojevi ne mogu razviti. Usprkos tome Carr ističe kako smo previše pod utjecajem tehnologije, a manje pod utjecajem vlastitog „softvera“ - uma i intuicije. Uz dubinsko čitanje i razmišljanje, suosjećajnost i empatija istaknute su kao osobine koje isto tako mogu doživjeti promjene pod utjecajem tehnologije. Epilogom Ljudski elementi autor privodi knjigu kraju izražavajući općepoznatu bojazan od toga da se ljudska inteligencija posve izgubi u umjetnoj.

Plitko potiče na razmišljanje na dvjema razinama. Jedna je osobna razina, koja podrazumijeva samopropitivanje kako funkcioniramo u navedenom ambijentu i jesmo li „plitki“. Druga je mnogo kompleksnija te zahtjevnija, pokušati sagledati sve „odozgo" i promatrati samu promjenu kao promjenu paradigme u određenom povijesnom kontekstu. Iako autor nastoji argumentirano ukazati da Internet relativno nepovoljno mijenja naš mentalni sklop, nedovoljno uzima u obzir protuargumente i prednosti korištenja takve tehnologije. „Obrana“ knjige od novih medija na trenutke je pomalo iracionalna. No nedostatak potpune objektivnosti u ovom slučaju ne umanjuje pozitivan dojam cjelokupnog djela. Riječ je o vrlo zanimljivoj knjizi koja je s razlogom postigla velik uspjeh.

Ana Petrić 